\title{
PROSES AKULTURASI KERUANGAN KOMUNITAS MUSLIM KAMPUNG JAWA DI PERKOTAAN TABANAN BALI
}

\begin{tabular}{|c|}
\hline Rahma Rizqyani' $^{\mathbf{1}}$, Agam Marsoyo \\
\hline${ }^{1,2}$ Magister Perencanaan Wilayah dan Kota Universitas Gadjah Mada \\
${ }^{1}$ rahmarzq@ gmail.com, ${ }^{2}$ agam@ @um.ac.id
\end{tabular}
Diterima: Maret 2019; Direvisi: April 2019; Disetujui: Mei 2019

\begin{abstract}
The traditional rules of Bali regulate the use of space as a manifestation of the rules of palemahan in the Tri Hita Karana concept. The arrival of Moslem migrants to Tabana urban area forms the Moslem community of Kampung Jawa which is the largest Moslem community in the Tabanan urban area and still exists today. The high intensity of interaction between Moslems and Hindus has resulted in spatial acculturation related to the rules of palemahan. This research aims to find out the process of spatial acculturation of the Moslem community in urban Tabanan Bali. The method used was a case study method with the Kampung Jawa area as a case unit. Data collection of case evidence was obtained through observation and in-depth interviews to the informant who are considered to have knowledge of the variety and spatial acculturation processes that occur and supported by other secondary data. This study found a different process and time of formation in each type of spatial acculturation that occurred. Spatial acculturation of the Moslem community of the Kampung Jawa in Tabanan urban takes several stages of the process, namely: (1) social interaction, (2) Moslem understanding of Hinduism, (3) Moslem adaptation, (4) Hindus understanding of Moslems, (5) acculturation, and (6) expansion of space, actors, and type of spatial acculturations.
\end{abstract}

Keyword: adaptation, interaction, spatial acculturation, process

Abstraksi. Aturan adat Bali mengatur pemanfatan ruang sebagai wujud aturan palemahan dalam konsep Tri Hita Karana. Kedatangan migran Muslim ke kawasan perkotaan Tabanan membentuk komunitas Muslim Kampung Jawa yang merupakan komunitas Muslim terbesar di kawasan perkotaan Tabanan dan masih eksis hingga saat ini. Tingginya intensitas interaksi Muslim dan warga Hindu mengakibatkan terjadinya akulturasi keruangan terkait dengan aturan palemahan. Penelitian ini bertujuan untuk menemukan proses akulturasi keruangan komunitas Muslim di perkotaan Tabanan Bali. Metode yang digunakan adalah metode studi kasus dengan kawasan Kampung Jawa sebagai unit kasus. Pengumpulan data bukti-bukti kasus diperoleh melalui observasi dan wawancara mendalam kepada narasumber yang dinilai memiliki pengetahuan terhadap ragam dan proses akulturasi keruangan yang terjadi dan didukung dengan data sekunder lainnya. Penelitian ini menemukan adanya proses dan waktu pembentukan yang berbedabeda pada tiap ragam akulturasi keruangan yang terjadi. Akulturasi keruangan komunitas Muslim Kampung Jawa di perkotaan Tabanan menempuh beberapa tahapan proses, yaitu: (1) interaksi sosial, (2) pemahaman Muslim terhadap Hindu, (3) Adaptasi Muslim, (4) pemahaman warga Hindu terhadap Muslim, (5) akulturasi, dan (6) perluasan ruang, pelaku, dan ragam akulturasi keruangan.

Kata kunci: adaptasi, akulturasi keruangan, interaksi, proses 


\section{PENDAHULUAN}

Kawasan Perkotaan Tabanan bukan merupakan kota administratif, melainkan fungsional. Dalam Peraturan Daerah Kabupaten Tabanan Nomor 11 Tahun 2012 tentang Rencana Tata Ruang Wilayah Kabupaten Tabanan Tahun 2012-2032, disebutkan bahwa kawasan Perkotaan Tabanan ini untuk wilayah Kecamatan Tabanan meliputi Desa Dauh Peken, Desa Delod Peken, Dajan Peken, dan Desa Denbantas. Adapun dari keempat desa ini, komunitas Muslim terbesar ditemukan pada Kampung Jawa yang merupakan bagian dari wilayah Desa Dauh Peken.

Komunitas Muslim berkembang pesat sekitar tahun 1970 dengan adanya migrasi besar-besaran seiring dengan perkembangan pariwisata di Bali (Drysdale, 1995; Mantra, 1993). Eksistensi migran Muslim membuktikan kemampuan para migran Muslim untuk berakulturasi dengan masyarakat adat Hindu di wilayah perkotaan Tabanan. Mashad (2014) menyampaikan bahwa masyarakat adat Bali memiliki konsep Tri Hita Karana yang dianut oleh warga adat Hindu yang mengatur hubungan antar manusia (pawongan), lingkungan (palemahan), dan Tuhan (parahyangan). Dalam konsep keruangan terkait dengan aturan palemahan dapat dipastikan sudah terjadi akulturasi unsur-unsur ruang antara Muslim dan Hindu, terutama mengenai pemanfaatan ruang untuk kegiatan Muslim, Hindu, atau keduanya.

Konflik pemanfaatan ruang antar masyarakat dengan latar belakang perbedaan agama dan kepercayaan sangat sering terjadi di Indonesia. Akan tetapi di kawasan perkotaan Tabanan belum pernah terjadi konflik pemanfaatan ruang antara Muslim dengan masyarakat adat Hindu meskipun ajaran agama keduanya sangat bertentangan. Bahkan Kabupaten Tabanan pada tahun 2017 menerima penghargaan "Harmony Award" dari Kementerian Agama atas keberhasilan dalam memelihara kerukunan beragama dan memfasilitasi kegiatan umat beragama.

Kondisi kerukunan antar umat beragama yang sangat baik ini semakin memperkuat asumsi adanya akulturasi yang terjadi, terutama antara warga Muslim sebagai pemeluk agama terbesar kedua di kawasan perkotaan Tabanan dan warga adat Hindu sebagai penduduk asli kawasan perkotaan Tabanan. Oleh karena itu perlu diteliti mengenai proses-proses yang telah dilalui hingga terbentuk akulturasi keruangan seperti saat ini yang berujung pada terciptanya kerukunan antara warga Muslim dan Hindu yang sangat baik. Tahapan proses yang dilalui tersebut dapat menjadi best practice bagi wilayah lain untuk menumbuhkan kesadaran masyarakat umum untuk saling menghormati perbedaan antar etnis dan agama sehingga mencegah terjadinya konflik antar etnis dan agama.

Penelitian mengenai akulturasi antara migran Muslim dan warga adat Hindu Bali pada umumnya berfokus pada hasil akulturasi. Akulturasi yang berfokus pada pola-pola arsitektur permukiman diteliti oleh Prasetya (2012) mengambil lokasi di Desa Pegayaman Buleleng Bali. Sementara itu Saputra (2014) melakukan penelitian di Desa Muslim Soko Kecamatan Penebel yang berfokus pada proses perubahan pola ruang permukiman sebagai wujud akulturasi arsitektur masyarakat tradisional Bali dan masyarakat Muslim. Kampung Jawa sendiri telah diteliti mengenai perkembangan fisik ruangnya oleh Dwipayana (2015). Dari penelitianpenelitian sebelumnya ini, belum pernah ada yang meneliti tentang proses akulturasi keruangan antara komunitas Muslim 
Kampung Jawa dan masyarakat adat Hindu di kawasan perkotaan Tabanan.

Bakker (1984) menyatakan bahwa proses akulturasi bermula dengan masih adanya adanya batas perbedaan budaya yang terlihat jelas, kemudian tumpang tindih satu sama lain. Tumpang tindih kebudayaan ini berlangsung lapisan demi lapisan yang semakin lama terjadi semakin luas dan dalam. Lebih jauh lagi, Kim (2001) menyatakan bahwa akulturasi berawal ketika migran mulai berinteraksi dengan pribumi setelah melalui proses sosialisasi sebelumnya. Sebelum terjadi akulturasi, ada proses enkulturasi/adaptasi budaya untuk mempertahankan eksistensi migran. Sementara itu, Dearborn (2008) mengemukakan bahwa di dalam akulturasi keruangan meskipun ada usaha untuk mempertahankan kebudayaan daerah asal, secara perlahan tetap terjadi transformasi budaya secara luas mendekati budaya wilayah yang ditempatinya. Transformasi ini meliputi bentuk dan arti tempat tinggal beserta manusia, kegiatan, dan segala hal yang ada di dalamnya. Dari beberapa teori yang dikemukakan oleh para ahli tersebut di atas, belum ada yang mengungkapkan secara jelas dan rinci mengenai tahapantahapan yang ditempuh dalam proses akulturasi keruangan.

Penelitian ini bertujuan untuk menemukan proses akulturasi keruangan komunitas Muslim Kampung Jawa di perkotaan Tabanan Bali. Tahapan-tahapan yang ditempuh dalam proses akulturasi keruangan terutama yang terjadi pada akulturasi keruangan antara komunitas Muslim Kampung Jawa dan masyarakat adat Hindu Bali di kawasan perkotaan Tabanan diungkapkan secara rinci dalam penelitian ini. Hal ini dimaksudkan untuk melengkapi teori-teori mengenai proses akulturasi keruangan yang sudah ada sebelumnya serta memperkaya penelitian mengenai akulturasi antara komunitas Muslim dengan masyarakat adat Hindu Bali.

\section{METODE PENELITIAN}

Pendekatan penelitian ini adalah pendekatan studi kasus. Penelitian mengenai akulturasi merupakan penelitian yang tidak pernah lepas dari permasalahan budaya. Menurut Endraswara (2006), dengan menggunakan metode studi kasus maka permasalahan kebudayaan akan terangkat ke permukaan, celah-celah kehidupan budaya yang tidak wajar dapat muncul. Selain itu metode studi kasus dapat mengkaji budaya secara naturalistik, holistik, dan fenomenologis.

Untuk mengungkapkan bagaimana proses akulturasi keruangan komunitas Muslim di perkotaan Tabanan, maka penelitian ini mengunakan single case design. Dalam single case design ini, unit kasus yang dipilih merupakan kasus yang unik dan memiliki nilai interaktif yang tinggi (Stake, 2006). Unit kasus yang dipilih dalam penelitian ini adalah Kampung Jawa yang merupakan tempat komunitas Muslim tertua di kawasan perkotaan Tabanan. Adapun unit kasus ini dipilih melalui proses grandtour yang dilaksanakan pada tahap persiapan.

Tahapan selanjutnya merupakan tahap pengumpulan data. Dalam kegiatan pengumpulan data penelitian ini, sumbersumber bukti kasus yang digunakan antara lain diperoleh melalui wawancara, observasi, dan pengumpulan data sekunder. Wawancara mendalam (in-depth interview) dilakukan kepada narasumber yang dinilai memiliki pengetahuan terhadap ragam dan proses akulturasi keruangan yang terjadi. Hasil wawancara kemudian dikonfirmasi melalui kegiatan focuss group discussion 
$(F G D)$. Observasi dilakukan pada ruang publik, ruang privat Muslim dan ruang privat Hindu di Kampung Jawa dan sekitarnya karena akulturasi keruangan sangat dimungkinkan terjadi pada ruangruang interaksi Muslim dan warga Hindu yang berada di luar wilayah Kampung Jawa namun tetap berada pada kawasan perkotaan Tabanan. Observasi ini berkaitan dengan pemanfaatan ruang untuk aktivitas Muslim dan Hindu yang bukan hanya berupa aktivitas keagamaan, melainkan juga termasuk aktivitas-aktivitas lain yang menjadi ciri khas masing-masing warga Muslim maupun Hindu. Sedangkan data sekunder berasal dari instansi pemerintah dan organisasi kemasyarakatan setempat untuk mendukung bukti-bukti kasus.

Tahapan terakhir dalam penelitian ini adalah analisis dan pelaporan. Seluruh bukti-bukti kasus yang diperoleh di lapangan baik itu melalui observasi, wawancara, maupun dokumen-dokumen sekunder dilakukan analisis mengenai proses akulturasi keruangan yang terjadi. Adapun teknik analisa yang digunakan adalah induktif melalui proses coding, menghubungkan tema-tema, dan interpretasi tema-tema untuk memunculkan tahapan-tahapan serta urutan rangkaian masing-masing tahapan proses akulturasi keruangan tersebut. Analisa ini dilakukan pada masing-masing ragam akulturasi keruangan yang ditemukan di lapangan. Selanjutnya dilakukan analisa untuk menemukan tahapan proses akulturasi keruangan komunitas Muslim Kampung Jawa di Perkotaan Tabanan beserta analisa mengenai temuan penelitian yang dapat memberikan kontribusi teoretik. Analisa proses akulturasi keruangan komunitas Muslim Kampung Jawa di perkotaan Tabanan Bali dilakukan dengan generalisasi kualitatif pada proses akulturasi keruangan pada masing-masing ragam akulturasi keruangan yang terjadi. Kontribusi teoretik dilakukan dengan membandingkan temuantemuan penelitian dengan teori-teori yang sudah ada sebelumnya. Seluruh hasil analisis dibuat eksplanasi dalam bentuk naratif. Gambar 1 menyajikan rangkaian alur proses penelitian.

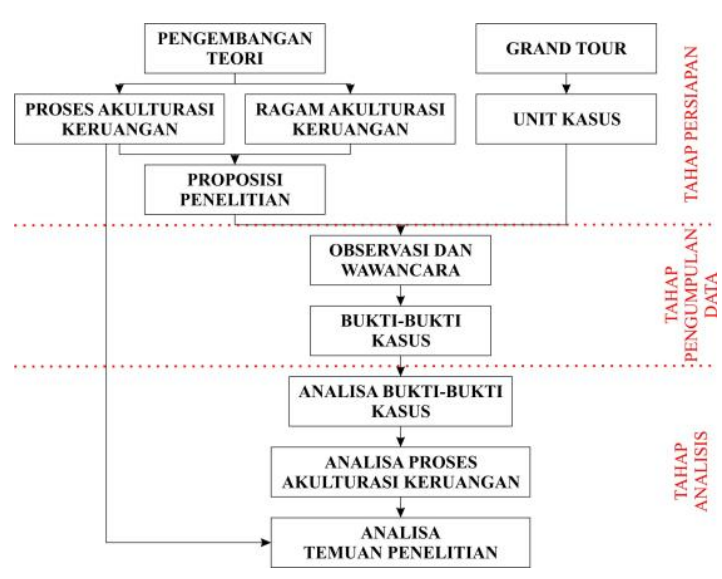

Gambar 1. Diagram Alir Penelitian

Sumber: Analisis peneliti, 2018

\section{HASIL DAN PEMBAHASAN}

\section{Hasil Penelitian}

\section{Gambaran Umum Kampung Jawa}

Kampung Jawa secara administratif masuk ke dalam wilayah Banjar Tunggalsari dan Banjar Tegal Belodan Desa Dauh Peken, Kecamatan Tabanan. Istilah Kampung Jawa bukan merupakan wilayah administratif tetapi muncul karena mayoritas warga di kawasan ini berasal dari Jawa dan Madura.

Pada awalnya komunitas Muslim Kampung Jawa hanya terdapat di Banjar Tunggalsari. Komunitas Muslim Kampung Jawa mengalami perkembangan pesat antara tahun 1966-1970, dan sejak tahun 1985 mulai menyebar ke daerah Kampung Kodok yang berada di sebelah selatan Banjar Tunggalsari (Dwipayana, 2015). Pada tahun 1980 jumlah warga Muslim di Kampung Jawa sekitar $300 \mathrm{KK}$ dan saat ini 
sudah berkembang menjadi lebih dari 700 KK pada banjar Tunggalsari dan sekitar 250 KK pada banjar Tegal Belodan.

Pesatnya perkembangan Muslim dicirikan dengan perkembangan permukiman Muslim ke arah luar Kampung Jawa. Hal ini berakibat pada percampuran lokasi tempat tinggal antara Muslim dan Hindu. Kondisi demikian menyebabkan intensitas interaksi yang tinggi antara Muslim dan warga Hindu, apalagi keberadaan Muslim diterima dengan baik oleh warga Hindu setempat. Bahkan warga Hindu Bali sudah menganggap Muslim sebagai nyama selam (saudara Muslim). Kedekatan hubungan ini berdampak pada adanya kesalingpemahaman dalam pemanfaatan ruang.

Ruang dimanfaatkan untuk melakukan aktivitas manusia. Semakin banyak manusia yang tinggal di suatu tempat, maka semakin kompleks aktivitas kelompok manusia tersebut. Hal ini akan mengakibatkan pemanfaatan ruang yang sama dengan pembauran berbagai aktivitas manusia tersebut (Doxiadis, 1971). Di sinilah akulturasi keruangan terjadi.

Migran Muslim dan warga asli Hindu memiliki aktivitas yang sangat berbeda. perbedaan ini tidak hanya mengenai aktivitas keagamaan, namun juga aktivitas dalam kehidupan sehari-hari. Oleh karena itu di dalam akulturasi keruangan, tidak hanya mengenai pemanfaatan ruang untuk aktivitas keagamaan, melainkan aktivitas apapun yang menjadi ciri khas migran Muslim maupun warga adat Hindu. Adapun akulturasi keruangan yang ditemukan di kawasan Kampung Jawa adalah: adanya kios baju bekas Pasar Kodok yang dimiliki oleh warga Hindu Bali; adanya kegiatan pengajian pada tanah milik warga Hindu; adanya rumah duka di kawasan kuburan Muslim Tunggalsari; dan adanya ruang parkir jamaah masjid di badan jalan.



Gambar 2. Sebaran Akulturasi Keruangan Islam-Hindu Kampung Jawa Sumber: Observasi dan wawancara peneliti, 2018 
Proses Akulturasi Keruangan pada Kios Baju Bekas Milik Pedagang Hindu di Pasar Kodok

Mayoritas Muslim Kampung Jawa bermatapencaharian sebagai pedagang. Pedagang yang berasal Sumenep sebagian besar berjualan pakaian bekas di Pasar Kodok yang merupakan wilayah Banjar Tegal Belodan. Pasar Kodok merupakan pasar baju bekas impor yang mulai muncul sekitar tahun 2000. Saat itu hanya terdapat sekitar 10 pedagang dari Pulau Raas, Madura yang menempati kios di sebelah timur pasar saat ini. Seiring waktu berjalan, kios berkembang ke arah barat hingga terbentuk Pasar Kodok seperti sekarang. Kios-kios di Pasar Kodok menempati lahan yang disewa dari warga Hindu. Pemilik lahan hanya membuat batas petak kios, sementara pedagang penyewa yang membuat sendiri bangunan kiosnya.

Pedagang Muslim Pasar Kodok sebagian besar tinggal di sekitar Pasar Kodok dengan menyewa bangunan ataupun tanah milik warga Hindu. Percampuran lokasi tempat tinggal pedagang Muslim dan warga Hindu menyebabkan keeratan hubungan sosial antara Muslim dan warga Hindu. Dalam hubungan ini terjadi transfer pengetahuan mengenai cara berdagang orang Muslim, seperti dimana mereka mengambil barang dagangan, bagaimana memperlakukan barang dagangan, serta cara menjual barang dagangan. Hal tersebut didasari oleh pemahaman Muslim terhadap kondisi perekonomian warga Hindu, terutama yang bekerja dalam bidang pertanian. Dengan demikian dapat dikatakan bahwa perilaku berbagi ilmu pengetahuan ini merupakan perwujudan dari perilaku adaptasi pedagang Muslim terhadap kondisi perekonomian warga Hindu setempat.
Pedagang Muslim meraup keuntungan yang sangat besar. Hal ini menjadi pendorong bagi warga Hindu untuk melakukan aktivitas yang sama. Sekitar tahun 2005 beberapa warga Hindu memulai usaha berdagang pakaian bekas pada tanahnya yang semula disewakan kepada pedagang Muslim dengan berbekal pengetahuan yang diperoleh dari pedagang Muslim. Pada tahap inilah akulturasi keruangan telah berlangsung, dimana pada ruang privat warga Hindu terdapat warga Hindu yang melakukan aktivitas seperti yang dilakukan oleh Muslim (pedagang Muslim). Kesuksesan warga Hindu berdagang pakaian bekas memicu warga Hindu lainnya untuk berdagang pakaian bekas baik di kios milik pribadi maupun kios sewa. Di sinilah tahap perluasan ruang dan pelaku akulturasi keruangan berlangsung. Kios pakaian bekas milik pribadi warga Hindu berada di dalam Pasar Kodok bercampur dengan pedagang Muslim lainnya. Sedangkan kios sewa berada di sebelah utara Pasar Kodok. Dengan demikian, tahapan proses akulturasi keruangan yang dilalui pada ragam ini adalah: (1) sosialisasi/interaksi sosial antara Muslim dan warga Hindu, (2) pemahaman kondisi perekonomian warga Hindu, (3) adaptasi, (4) akulturasi, dan (5) perluasan ruang dan pelaku akulturasi.

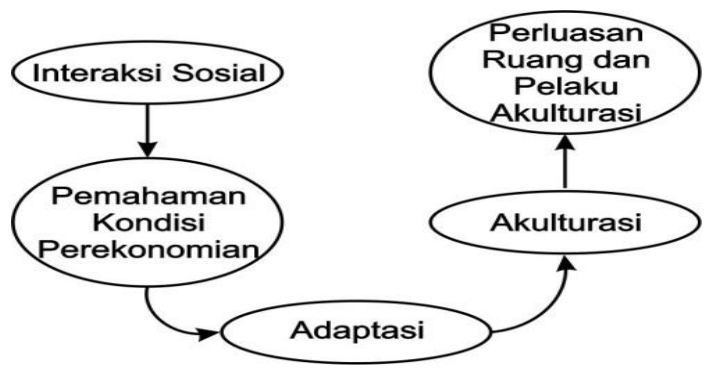

Gambar 3. Tahapan Proses Akulturasi Keruangan pada Kios Baju Bekas Sumber: Analisis peneliti, 2019 


\section{Proses Akulturasi Keruangan pada Kegiatan Pengajian di Tanah Milik Warga Hindu}

Sebagian besar bangunan sewa tempat tinggal komunitas Muslim sekitar Pasar Kodok berupa rumah-rumah petak yang berukuran kecil. Seperti komunitas Muslim pada umumya, komunitas Muslim di kawasan ini juga rutin mengadakan acara keagamaan seperti pengajian. Pada rumahrumah kecil inilah kegiatan pengajian dilaksanakan secara bergilir. Keterbatasan ruang bagi warga Muslim untuk melakukan aktivitas keagamaan mendorong warga Muslim untuk memanfaatkan badan jalan ataupun gang yang merupakan area publik. Area publik ini tidak hanya digunakan oleh warga Muslim sehingga aturan-aturan adat sosial kemasyarakatan sangat diperhatikan oleh warga Muslim. Aturan adat sangat dipahami melalui interaksi sosial dengan warga Hindu setempat. Oleh karena itu dalam setiap kegiatan keagamaan, warga Muslim selalu melaporkan kegiatannya kepada perangkat banjar setempat. Hal ini merupakan perilaku adaptasi warga Muslim terhadap aturan adat Hindu.

Di lain sisi, kondisi demikian sangat dipahami oleh warga Hindu karena dalam ajaran agama Hindu sangat menjunjung tinggi toleransi antar umat beragama. Adanya toleransi ini ditunjukkan dengan adanya bantuan pecalang adat secara sukarela apabila diminta bantuannya untuk mengatur penggunaan ruang publik dalam pelaksanaan kegiatan keagamaan Muslim. Adanya keterlibatan pecalang dalam pengaturan penggunaan ruang publik bagi aktivitas keagamaan Muslim ini sudah merupakan tahap akulturasi.

Penggunaan ruang publik oleh Muslim memunculkan ide bagi salah satu warga Hindu untuk menyewakan tanah kosong yang dimilikinya sebagai tempat pelaksanaan pengajian dengan maksud untuk meningkatkan kenyamanan pengguna jalan. Ide ini disampaikan kepada warga Muslim melalui interaksi sosial sehari-hari. Penawaran ini disambut baik oleh warga Muslim karena dapat memberikan kesempatan untuk melaksanakan kegiatan keagamaan dalam skala yang lebih besar, seperti pengajian akbar dalam rangka perayaan hari besar Islam. Pada akhirnya terjadilah akulturasi keruangan yang lebih dalam, dimana aktivitas keagamaan Muslim tidak hanya dilakukan pada ruang publik melainkan pada ruang privat milik warga Hindu. Kegiatan pengajian pada ruang privat Hindu ini sudah berlangsung selama beberapa tahun dengan sistem sewa.

Dari uraian tersebut di atas, terlihat bahwa tahapan proses akulturasi keruangan pada ragam ini meliputi : (1) interaksi sosial, (2) pemahaman warga Muslim terhadap aturan adat Hindu, (3) adaptasi, (4) pemahaman warga Hindu terhadap kebutuhan ruang aktivitas Muslim, (5) akulturasi, dan (6) akulturasi keruangan yang lebih dalam.

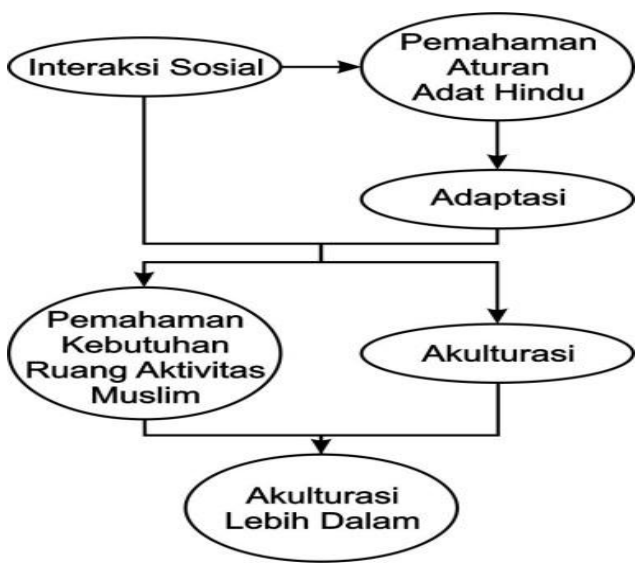

Gambar 4. Tahapan Proses Akulturasi Keruangan pada Kegiatan Pengajian di Tanah Milik Warga Hindu Sumber: Analisis peneliti, 2019 


\section{Proses Akulturasi Keruangan pada Rumah Duka di Kawasan Kuburan Muslim}

Pengaturan hubungan manusia dengan lingkungannya (palemahan) dalam kehidupan adat Hindu diwujudkan dengan pengaturan pola pemanfaatan ruang. Hal ini ditujukan untuk mendukung kekhusyukan dalam menjalankan ibadah. Pengaturan ruang ini tidak hanya berlaku pada tempat tinggal warga Hindu, tetapi meliputi ruangruang disekitarnya, termasuk ruang-ruang yang ditinggali oleh warga non Hindu. Meskipun demikian, dalam pelaksanaan aturan adat ini tetap mempertimbangkan konsep rwa bhineda (dua hal yang berbeda atau bertentangan). Konsep ini membentuk warga adat Hindu Bali yang sangat menghargai adanya perbedaan dan sangat toleran terhadap pemeluk agama lain. Perbedaan tersebut terbentuk dari konsep desa (ruang), kala (waktu), patra (keadaan riil di lapangan), sehingga dalam pelaksanaan aturan adat Hindu cukup fleksibel menyesuaikan ruang, waktu, dan kondisi. Dalam hal ini tidak semua aturan adat Hindu diberlakukan bagi warga non Hindu.

Fleksibilitas pemberlakuan aturan adat Hindu terhadap warga Muslim tergantung kepada jenis kepemilikan ruang. Pada Muslim yang menguasai ruang dengan status hak milik pribadi, aturan adat Hindu yang berlaku hanya sebatas aturan yang mengatur hubungan kemasyarakatan. Akan tetapi bagi warga Muslim yang tidak memiliki kuasa atas ruang yang ditempatinya, yaitu yang tinggal dengan cara menyewa ruang milik warga Hindu, diberlakukan aturan yang lebih daripada itu. Ketiga konsep Tri Hita Karana (parahyangan, palemahan, dan pawongan) tetap dipelihara dengan baik pada ruangruang ini.
Pemberlakuan ketiga konsep tersebut dalam prakteknya adalah adanya penyucian terhadap cuntaka (keadaan tidak suci). Kejadian kematian merupakan salah satu kondisi cuntaka. Kondisi cuntaka ini dipercaya akan membawa pengaruh buruk kedepannya, sehingga perlu dilakukan upacara mecaru (penyucian). Dengan hilangnya pengaruh buruk tersebut, maka keharmonisan hubungan manusia dengan lingkungan kembali seperti semula. Ritual mecaru memerlukan biaya yang besar. Oleh karena itu dianjurkan agar tidak ada kejadian Muslim yang meninggal di rumah sewa/kosnya.

Aturan tidak tertulis ini sudah sangat dipahami oleh warga Muslim yang sudah lama tinggal di kawasan Kampung Jawa melalui interaksi sosial dengan warga Hindu setempat. Bagi migran Muslim yang masih baru, aturan ini diketahui dari warga Hindu setempat dan warga Muslim yang sudah lebih dulu tinggal di tempat tersebut. Interaksi sosial antara Muslim dan warga Hindu terjalin sangat baik. Warga Muslim maupun Hindu terutama pemilik rumah sewa sama-sama mengingatkan apabila ada seorang Muslim yang sakit parah agar segera dibawa ke rumah sakit supaya tidak terjadi kejadian kematian di rumah warga Hindu.

Permasalahan yang dialami oleh Muslim penyewa rumah tidak berhenti sampai disitu saja, karena mereka membutuhkan tempat untuk merawat jenazah (memandikan, mengkafani dan mensholatkan). Oleh karena itu, Yayasan Marzuki yang juga mengorganisir mengenai kifayah (urusan duka) Kampung Jawa, membangun rumah duka di dalam kawasan kuburan Muslim. Sebelum adanya bangunan rumah duka di kawasan kuburan Muslim, ritual perawatan jenazah dilakukan di dalam Masjid Agung Tabanan. Upaya 
menghindari kejadian meninggal dan perawatan jenazah dan adanya rumah duka dalam kawasan kuburan Muslim merupakan wujud adaptasi warga Muslim Kampung Jawa terhadap aturan adat Hindu. Dengan adanya aturan adat Hindu, Muslim yang tinggal di rumah sewa milik warga Hindu tidak lagi mengurus jenazah di rumah duka. Dengan demikian keberadaan rumah duka di kawasan kuburan Muslim merupakan wujud dari adaptasi keruangan dan belum sampai pada proses akulturasi keruangan.

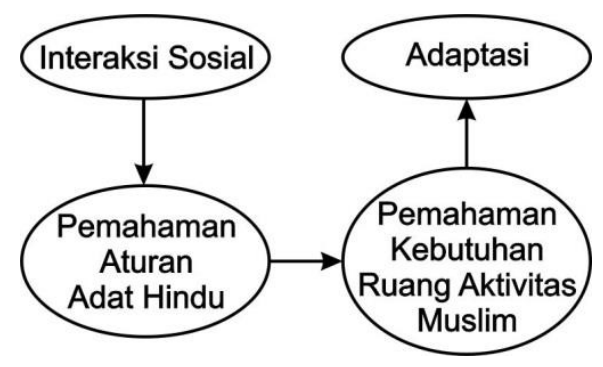

Gambar 5. Tahapan Proses Akulturasi Keruangan pada Rumah Duka di Kawasan Kuburan Muslim

Sumber : Analisis peneliti, 2019

\section{Proses Akulturasi Keruangan pada Ruang Parkir Jamaah Masjid di Badan Jalan}

Komunitas Muslim pada masa keruntuhan Kerajaan Tabanan (sekitar tahun 1906) diberikan tempat permukiman dan dua bidang tanah untuk areal masjid dan kuburan. Pada awalnya masjid di kawasan Kampung Jawa ini berada di Kampung Jawa bagian utara (Jalan Kenyeri) kemudian pada tahun 1977 seiring dengan perkembangan pesat penduduk Muslim, maka lokasi masjid dipindahkan ke bagian tengah Kampung Jawa, tepatnya di Jalan Kamboja.

Jl. Kamboja merupakan jalur ramai karena merupakan jalan searah yang menghubungkan pusat perkotaan Tabanan dengan jalan bypass. Posisi Masjid Agung
Tabanan tepat berada di pinggir jalan tanpa adanya ruang parkir di dalam kawasan masjid. Sementara itu sebagai masjid agung yang merupakan masjid terbesar di wilayah perkotaan Tabanan, jamaah yang berkunjung ke masjid ini sangat banyak, terutama pada waktu pelaksanaan ibadah khusus, seperti hari jumat dan hari raya. Jamaah yang berkunjung ke masjid ini tidak hanya warga Muslim Kampung Jawa saja, melainkan warga-warga Muslim di sekitar perkotaan Tabanan maupun Muslim yang sedang melintas. Ketidaktersediaan ruang parkir di dalam areal masjid mengakibatkan penggunaan ruang di pinggir Jalan Kamboja serta gang-gang kecil di sekitarnya (Jalan Belimbing) sebagai ruang parkir.

Sekitar Masjid Agung Tabanan terutama di Jalan Kamboja dan Jalan Belimbing terdapat banyak tempat tinggal warga Hindu. Warga Hindu yang menganggap Muslim sebagai nyama selam tidak merasa keberatan atas penggunaan ruang publlik ini. Toleransi ini merupakan wujud adanya pemahaman warga Hindu terhadap kebutuhan ruang aktivitas Muslim. Pemahaman ini muncul karena adanya interaksi sosial yang sangat intensif antara warga Muslim dengan warga Hindu. Dalam penggunaan ruang publik sebagai tempat parkir jamaah masjid, warga Muslim selalu berkoordinasi dan melibatkan perangkat adat dan perangkat keamanan baik itu kepolisian, petugas keamanan Yayasan Marzuki, maupun pecalang adat Hindu.

Koordinasi Muslim dengan perangkat adat setempat dalam penggunaan ruang publik ini ditujukan untuk menjaga keharmonisan hubungan Muslim dengan Hindu. Hal ini merupakan perilaku adaptasi yang dilakukan oleh warga Muslim karena pada awalnya muncul kekhawatiran mengenai penyalahgunaan pemanfaatan 
ruang menurut ajaran yang dianut oleh warga Hindu sekitar masjid. Kondisi akulturasi keruangan adalah ketika digunakannya ruang publik di sekitar tempat tinggal warga Hindu sebagai ruang parkir jamaah masjid dan adanya pecalang adat yang terlibat dalam pengaturan keamanan pada ruang parkir tersebut. Gambar 6. Menyajikan skema tahapan proses akulturasi keruangan yang dilalui pada penggunaan ruang publik sebagai ruang parkir jamaah Masjid Agung Tabanan.

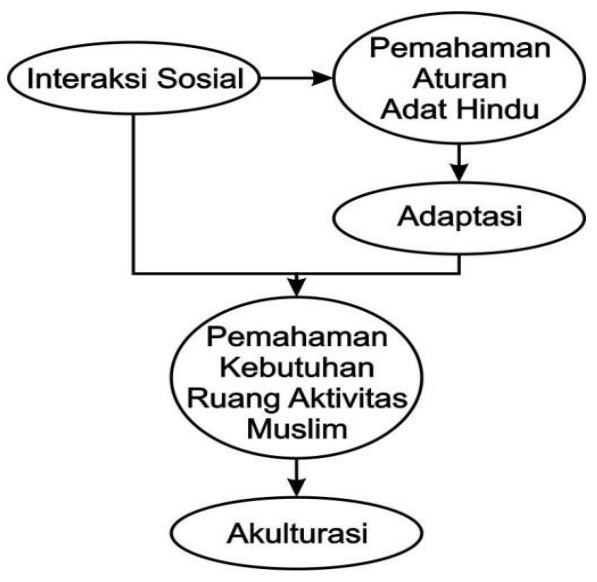

Gambar 6. Tahapan Proses Akulturasi Keruangan pada Ruang Parkir Jamaah Masjid di Badan Jalan

Sumber : Analisis peneliti, 2019

\section{Pembahasan}

Untuk menemukan proses akulturasi keruangan komunitas Muslim Kampung Jawa di perkotaan Tabanan, dilakukan dengan melakukan generalisasi kualitatif pada masing-masing proses ragam akulturasi keruangan yang terjadi. Dari berbagai ragam akulturasi keruangan yang ditemukan di lokasi penelitian, setiap ragam menempuh proses, waktu kejadian, dan waktu tempuh proses yang berbeda-beda. Seluruh proses yang terjadi selalu diawali dengan adanya interaksi sosial antara warga Muslim dan Hindu. Hal ini sesuai dengan teori yang dikemukakan oleh Kim (2001) bahwa akulturasi terjadi ketika migran mulai berinteraksi dengan pribumi setelah melalui proses sosialisasi sebelumnya. Dengan demikian jelas bahwa tahapan pertama yang dilalui pada proses akulturasi keruangan komunitas Muslim Kampung Jawa di perkotaan Tabanan adalah tahapan interaksi sosial.

Bakker (1984) menyatakan bahwa di dalam proses akulturasi keruangan akan terjadi tumpang tindih budaya yang berlangsung lapisan demi lapisan yang semakin lama semakin luas dan dalam. Akan tetapi tidak dijelaskan secara rinci mengenai tahapan-tahapan yang dilaluinya. Sementara itu Kim (2001) mengungkapkan bahwa sebelum terjadi akulturasi, terjadi proses adaptasi. Namun, bagaimana proses menuju adaptasi tidak dijelaskan lebih lanjut.

Berdasarkan temuan pada beberapa ragam akulturasi keruangan di Kampung Jawa diketahui bahwa dalam tahap interaksi sosial selalu ada penyampaian kondisi, karakteristik, maupun aktivitas dari masingmasing pelaku akulturasi. Dari aktivitas ini akan dicapai adanya pemahaman kondisi, karakteristik, maupun aktivitas antar masing-masing pelaku akulturasi. Apabila dicermati lebih mendalam, ternyata warga Muslim sebagai migran lebih dahulu memahami kondisi, karakteristik, maupun aktivitas para warga Hindu. Hal ini dilatarbelakangi oleh kemauan migran Muslim untuk tetap eksis di tempat tinggal barunya tanpa adanya konflik dengan warga Hindu sebagai tuan rumah. Pemahaman warga Muslim ini terutama pada aturan adat Hindu karena aturan adat Hindu mengatur aktivitas yang dilakukan dalam lingkungan itu termasuk lingkungan yang ditempati oleh warga Muslim. Kim dalam Lee (2018) juga mengungkapkan hal serupa, yaitu 
migran akan lebih memahami dan kemudian mengadopsi norma dan nilai yang berlaku dalam kelompok masyarakat tuan rumah. Dalam konteks ini, migran Muslim Kampung Jawa beradaptasi dengan melakukan perubahan aktivitas-aktivitas di dalam ruang yang menyesuaikan aturanaturan adat Hindu yang berlaku tanpa menyimpang dari aturan agama Islam. Adapun aturan-aturan adat Hindu di kawasan perkotaan Tabanan dituangkan ke dalam awig-awig Desa Pakraman Kota Tabanan.

Dalam berbagai ragam akulturasi keruangan yang terjadi pada komunitas Muslim Kampung Jawa di perkotaan Tabanan, tidak semua tahap adaptasi yang terjadi bersifat keruangan. Hanya pada rumah duka di kawasan kuburan Muslim saja yang adaptasinya merupakan adaptasi keruangan. Dengan demikian maka dalam proses akulturasi keruangan pada wilayah penelitian tidak hanya proses yang bersifat keruangan saja yang menyertainya, melainkan proses-proses non keruangan pun turut menyertainya. Proses non keruangan ini berupa proses adaptasi sosial dalam bentuk sharing informasi dan koordinasi dengan warga dan perangkat adat Hindu.

Pemahaman warga Muslim terhadap kondisi, karakteristik, dan aktivitas warga Hindu telah berlangsung. Akan tetapi kapankah warga Hindu sendiri memahami kondisi, karakteristik, dan aktivitas warga Muslim? Pada berbagai ragam akulturasi keruangan yang terjadi, kondisi ini tercapai setelah terjadinya kondisi adaptasi yang dilakukan oleh warga Muslim. Dalam hal ini warga Hindu melihat secara kasat mata aktivitas adaptasi yang dilakukan oleh warga Muslim dan kemudian timbul dengan sendirinya pemahaman tersebut. Hal ini didukung juga dengan adanya ajaran agama
Hindu mengenai hubungan antar manusia (pawongan) serta adanya anggapan bahwa Muslim merupakan nyama selam sehingga muncul sikap toleransi warga Hindu terhadap warga Muslim. Faktor yang menjembatani terjadinya kondisi pemahaman ini adalah adanya interaksi sosial antara warga Hindu dan Muslim yang terjalin dengan baik. Seperti dalam proses pemahaman warga Muslim terhadap aturan adat Hindu, warga Hindu juga mengetahui berbagai hal terkait warga Muslim juga melalui pemberitahuan dari mulut ke mulut dari warga Muslim sendiri maupun antar warga Hindu. Akan tetapi pemahaman yang dicapai oleh warga Hindu adalah pemahaman mengenai kebutuhan ruang bagi Muslim dalam melakukan aktivitasnya. Selain itu, terjadi pemahaman warga Hindu terhadap aktivitas non keagamaan Muslim yang dipandang dapat dilakukan juga oleh warga Hindu dan dinilai menguntungkan. Dengan demikian, maka dapat dikatakan bahwa tahapan pemahaman warga Hindu terhadap kondisi, karakteristik, dan kegiatan warga Muslim merupakan kelanjutan dari proses adaptasi dan proses interaksi sosial.

Pada saat warga Hindu sudah memahami mengenai kebutuhan ruang aktivitas warga Muslim, maka terjadilah kondisi akulturasi keruangan. Dalam tahap ini terjadi kondisi pemanfaatan ruang-ruang publik untuk kegiatan keagamaan Islam.

Replikasi aktivitas Muslim oleh warga Hindu dan pelaksanaan kegiatan keagamaan Islam pada ruang privat Hindu merupakan wujud akulturasi keruangan di tingkat lanjutan yang lebih dalam. Replikasi aktivitas Muslim oleh warga Hindu yang dimaksud di sini bukan merupakan aktivitas keagamaan, melainkan aktivitas sehari-hari yang menjadi ciri khas Muslim. Aktivitas keagamaan Muslim tidak hanya dilakukan 
oleh Muslim pada ruang publik saja tetapi sudah sampai pada ruang privat Hindu. Jadi dalam hal ini untuk aktivitas keagamaan tetap dilakukan oleh Muslim, hanya ruangnya saja yang semakin masuk ke dalam ruang Hindu, yaitu dari ruang publik ke ruang privat Hindu. Sementara untuk aktivitas non keagamaan Muslim, perluasannya kepada pelaku (warga Hindu) dan ruang privat Hindu. Meskipun demikian, tidak menutup kemungkinan adanya replikasi aktivitas kegamaan yang dilakukan oleh Muslim maupun warga Hindu. Dengan demikian terlihat jelas bahwa dalam tahap lanjutan ini terjadi peningkatan kedalaman dalam hal jenis kepemilikan ruang, serta terjadi perluasan ruang dan pelaku akulturasi.

Selain perluasan tersebut, akulturasi keruangan dalam tahap lanjutan juga terjadi perluasan ragam akulturasi keruangan. Pada berbagai ragam akulturasi keruangan yang terjadi di Kampung Jawa diketahui bahwa masing-masing ragam akulturasi keruangan memiliki waktu permulaan proses yang berbeda-beda. Hal ini menunjukkan bahwa seiring berjalannya waktu, akulturasi keruangan pun semakin beragam. Semakin beragamnya akulturasi keruangan yang terjadi muncul karena pada masing-masing tahapan proses terus berlangsung tanpa pernah terhenti dengan sempurna. Semakin banyaknya aturan-aturan adat Hindu yang dipahami oleh Muslim, maka akan semakin banyak pula adaptasi aktivitas Muslim terhadap aturan agama tersebut. Di sisi lain, semakin pahamnya warga adat Hindu terhadap aktivitas Muslim, tentu saja akan terjadi pemahaman kebutuhan ruang bagi Muslim untuk aktivitas keagamaan lainnya serta munculnya replikasi-replikasi aktivitas non keagamaan bahkan mungkin replikasi aktivitas keagamaan Muslim lainnya oleh warga adat Hindu. Kondisi seperti inilah yang akhirnya memunculkan semakin beragamnya akulturasi keruangan yang terjadi.

Proses akulturasi yang semakin luas dan semakin dalam ini sesuai dengan yang diungkapkan oleh Bakker (1984). Dalam hal ini, proses akulturasi keruangan komunitas Muslim Kampung Jawa di Perkotaan Tabanan memberikan penjelasan yang lebih detail mengenai teori yang dikemukakan oleh Bakker (1984), dimana perluasan akulturasi keruangan yang terjadi dalam hal ragam, pelaku dan ruang. Sementara tingkat kedalaman akulturasi keruangan adalah dalam hal status kepemilikan ruang tempat akulturasi terjadi dan jenis aktivitas yang direplikasi.

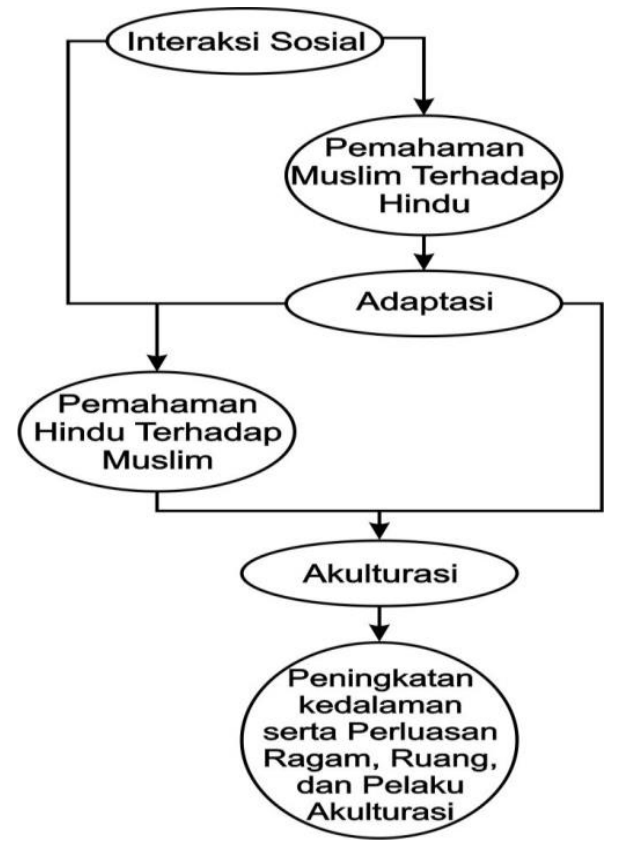

Gambar 7. Tahapan Proses Akulturasi Keruangan Komunitas Muslim Kampung Jawa di Perkotaan Tabanan Sumber: Analisis peneliti, 2019

\section{SIMPULAN}

Dari analisis dan pembahasan mengenai proses akulturasi keruangan dapat ditarik kesimpulan bahwa ada beberapa tahapan yang dilalui dalam proses 
akulturasi keruangan komunitas Muslim Kampung Jawa di perkotaan Tabanan, yaitu: (1) interaksi sosial; (2) pemahaman Muslim terhadap Hindu; (3) adaptasi; (4) pemahaman Hindu terhadap Muslim; (5) akulturasi; dan (6) peningkatan kedalaman serta perluasan ragam, ruang, dan pelaku akulturasi. Keenam tahapan ini berlangsung seiring dengan berjalannya waktu namun antar masing-masing tahapan proses dapat berlangsung pada waktu yang sama dan saling tumpang tindih satu sama lain. Satu tahapan proses tidak menunggu tahapan proses sebelumnya selesai dengan sempurna. Ketika tahapan lanjutan berlangsung, tahapan proses sebelumnya masih tetap berlangsung untuk memunculkan ragam akulturasi lainnya. Inilah yang menyebabkan semakin beragamnya akulturasi keruangan yang terjadi.

Adanya keenam tahapan proses akulturasi keruangan ini melengkapi teori yang dikemukakan oleh Bakker (1984) dan Kim (2001) bahwa selain tahapan interaksi sosial, adaptasi dan akulturasi selalu melalui tahapan saling pemahaman karakteristik antara migran dan penduduk asli. Kemudian setelah terjadi akulturasi, maka tingkat kedalaman akulturasi akan semakin bertambah serta ragam akulturasi, pelaku akulturasi, dan ruang-ruang akulturasi yang terjadi semakin meluas. Keempat temuan ini (tingkat kedalaman, ragam, pelaku, dan ruang) semakin memperjelas teori yang dikemukakan oleh Bakker (1984) mengenai proses akulturasi bahwa di dalam akulturasi akan terjadi tumpang tindih budaya yang berlangsung lapisan demi lapisan yang semakin lama terjadi semakin luas dan dalam.

Dengan memahami proses akulturasi keruangan maka dapat diprediksi kondisi-kondisi yang akan terjadi apabila sekelompok migran menetap pada suatu wilayah dengan karakter penduduk yang sangat berbeda. Prediksi ini tidak hanya berkaitan dengan aktivitas-aktivitas akulturasi saja, tetapi juga termasuk pemanfaatan ruang sebagai tempat akulturasi tersebut. Proses-proses akulturasi keruangan yang dilalui oleh komunitas Muslim Kampung Jawa dengan masyarakat adat Hindu di perkotaan Tabanan dapat menjadi contoh bagi wilayah lain untuk memberikan kesadaran bagi migran dan penduduk asli di wilayah lain. Dengan demikian, hal ini dapat menghindarkan konflik ruang antara migran dan penduduk asli ataupun antar komunitas penduduk dengan latar belakang etnis yang berbeda mengingat Negara Indonesia merupakan negara yang memiliki keberagaman etnis yang sangat tinggi.

\section{DAFTAR PUSTAKA}

Bakker. (1984). Filsafat Kebudayaan : Sebuah Pengantar. Yogyakarta: Kanisius.

Dearborn, L. M. (2008). Socio-spatial Patterns of Acculturation: Examining Hmong Habitation in Milwaukee's North-side Neighborhoods. Buildings \& Landscapes: Journal of the Vernacular Architecture Forum, 15, 58-77.

Doxiadis, C. A. (1971). Ekistics : An Introdustion To The Science of Human Settlements. London: Hutchinson \& Co. 
Drysdale, A. (1995). Sustainable Agriculture in Bali. In S. Martopo \& B. Mitchell (Eds.), Bali, Balancing Environment, Economy and Culture. Waterloo: Department of Geography Univesity of Waterloo.

Dwipayana, I. G. A. Y. (2015). Perkembangan Keruangan 'Kampung Jawa' di Kota Tabanan. (Thesis), Universitas Udayana, Denpasar.

Endraswara, S. (2006). Metodologi Penelitian Kebudayaan. Yogyakarta: Gadjah Mada University Press.

Kim, Y. Y. (2001). Becoming Intercultural: An Integrative Theory of Communication and Cross-Cultural Adaptation. California: SAGE Publications.

Lee, S. K. (2018). Refining a theory of cross-cultural adaptation: an exploration of a new methodological approach to institutional completeness. Asian Journal of Communication, 28(3), 315-334.

Mantra, I. B. (1993). Perubahan Struktur Penduduk Akibat Pembangunan Industri Pariwisata di Propinsi Bali. Populasi, 4 (1), 52 - 68.

Mashad, D. (2014). MUSLIM BALI; Mencari Kembali Harmoni yang Hilang. Jakarta: Pustaka Al-Kautsar.

Prasetya, L. E. (2012). Akulturasi Budaya Pada Masyarakat Muslim Desa Pegayaman Buleleng Bali. Jurnal Arsitektur Universitas Bandar Lampung, no. 2 vol. 2, juni $2012,56-63$.

Saputra, A. (2014). Arsitektur Permukiman Desa Muslim Soko Kecamatan Penebel, Kabupaten Tabanan, Bali. (Thesis), Universitas Gadjah Mada, Yogyakarta.

Stake, R. E. (2006). Multiple Case Study Analysis. New York: The Guilford Press. 